\title{
Ritual Mattompang Arajang Prosesi Penyucian Benda Pusaka Kerajaan Bone: Tinjauan Semiotik Budaya
}

\author{
Indarwati ${ }^{1}$, Nur Fadny Yuliani ${ }^{2}$, Lina Mariana ${ }^{3}$ \\ Politeknik Informatika Nasional \\ indarwatipolinas@gmail.com; nurfadny@gmail.com; \\ linamariana90@yahoo.co.id
}

\begin{abstract}
Abstrak
Penelitian ini menjadi salah satu media untuk mempublikasikan kekayaan budaya lokal yang selama ini terpendam di Kabupaten Bone dan kemudian dapat menjadi acuan bagi pemerintah lokal untuk lebih memperhatikan eksistensi dari keanekaragaman budaya masyarakat Indonesia dengan mendukung serta menjadi promoter dan fasilitator utama yang mendorong berkembangnya perbendaharaan kultur di Bumi Pertiwi khususnya di Kabupaten Bone. Melalui penelitian inilah diharapkan mampu memberi gambaran kepada masyarakat luas bahwa masyarakat setempat menyimpan sejuta pesona budaya yang layak disaksikan oleh mata dunia. Penelitian ini difokuskan pada semiotik budaya. Jenis penelitian ini adalah penelitian kualitatif. Data dikumpulkan dengan metode observasi, dengan teknik rekam, teknik catat, dokumentasi, dan wawancara. Data yang terkumpul kemudian dianalisis dengan teknik analisis deskriptifkualitatif. Penelitian dilakukan sekitar satu tahun, mulai pengumpulan data hingga analisis data dan pembuatan laporan. Lokasi pada penelitian ini, yaitu Kecamatan Watampone, Kabupaten Bone, Sulawesi Selatan. Hasil penelitian menunjukkan bahwa bentuk-bentuk ritual/prosesi dalam ritual Mattompang Arajang, yakni: ritual malekke toja (memindahkan atau mengambil air), ritual mappaota (mempersembahkan daun sirih), ritual masossoro/mattompang Arajang (membersihkan arajang/pusaka kerajaan), dan ritual mappatinro arajang (menidurkan/mengembalikan arajang). Adapun makna yang dapat diambil dengan adanya ritual mattompang arajang, yakni: adanya silaturahmi dan persatuan masyarakat Bone, makna membersihkan atau menyucikan benda-benda pusaka, Makna magis/spiritual, dan kelestarian budaya Kerajaan Bone.
\end{abstract}

Kata kunci: Ritual, Mattompang Arajang, Bone

\section{Pendahuluan}

\section{Latar Belakang}

Kebudayaan adalah sebuah sistem tanda yang memiliki beberapa peranan, di antaranya cara pemahaman, perhubungan, dan penciptaan. Kebudayaan juga merupakan sistem yang berupa gagasan, kelakuan, dan hasil kelakuan. Dengan kata lain, kebudayaan adalah hasil cipta, rasa, dan karsa manusia. Bentuk-bentuk simbolis yang berupa kata, benda, laku, mite, sastra, lukisan, nyanyian, musik, kepercayaan yang berkaitan erat dengan konsepkonsep dari sistem pengetahuannya, juga tidak dapat terpisahkan dari sistem sosial, organisasi kemasyarakatan, dan seluruh perilaku sosial.

Kabupaten Bone, di Sulawesi Selatan yang dikenal sebagai kota beradat yang menyimpan beragam keunikan dan estetika budaya sangat menghormati dan menjunjung tinggi budaya nenek moyang. Pada setiap peringatan Hari Jadi Bone, ritual "Mattompang Arajang" atau pembersihan benda-benda pusaka rutin selalu diadakan. Benda-benda pusaka tersebut disimpan di sebuah ruangan 
khusus di Sao Raja, kompleks rumah jabatan Bupati Bone. Pada upacara mattompang tersebut, benda-benda pusaka disakralkan bagai makhluk hidup.

Mattompang arajang adalah upacara adat yang sakral dengan mensucikan benda-benda pusaka kerajaan Bone. Prosesi tersebut biasa juga disebut dengan Mappepaccing arajang atau dikenal pula dengan istilah Pangadereng dilangiri. Benda-benda pusaka yang ditompang meliputi Teddung Pulaweng (Payung emas), Sembangeng Pulaweng (selempang emas), Kelewang LaTea RiDuni, Keris La Makkawa, Tombak La Sagala, Kelewang Alameng Tata Rapeng (Senjata adat tujuh atau Ade' Pitu). Pencucian benda pusaka tersebut menggunakan beberapa air sumur yang berada di Kabupaten Bone, yakni Bubung Parani, Bubung Bissu, Bubung Tello', dan Bubung Laccokkong. Sumber mata air ini dikumpulkan sebagai bahan pembersihan pusaka.

Pada zaman dahulu, mappepaccing arajang atau mattompang dilaksanakan oleh para Bissu atas restu Raja Bone atau Mangkau di dalam ruangan tempat penyimpanan arajang tersebut. Para Bissu dianggap mengetahui serta mampu berhubungan dengan kegaiban yang menyertai arajang atau benda pusaka tersebut. Oleh karena itu, secara religius, hanya para Bissulah yang dianggap mampu dan kapabel untuk menggerakkan dan memindahkan arajang (benda pusaka) dari tempatnya semula.

Ritual Mattompang Arajang ini merupakan sebuah ritual tahunan yang dilaksanakan oleh masyarakat dan pemerintah Kabupaten Bone dalam rangka penyucian benda-benda pusaka warisan Kerajaan Bone. Ritual tersebut sebagai salah satu pesta adat masyarakat, sekaligus pelestarian budaya Kerajaan Bone. Masyarakat Bone umumnya akan "pulang kampung" demi menyaksikan secara langsung prosesi dan ritual tersebut.

Penelitian ini penting dilakukan dalam rangka melestarikan dan mendokumentasikan ritual budaya lokal. Oleh karena generasi saat ini dan yang akan datang tentu akan sangat membutuhkan informasi yang akurat mengenai bentuk-bentuk ritual yang ada di masyarakat, salah satunya adalah ritual Mattompang Arajang ini. Selain itu, ritual ini rutin dilaksanakan setiap tahun sehingga dapat menjadi salah satu destinasi wisata budaya yang dapat menarik para wisatawan untuk berkunjung di Kabupaten Bone. Hal ini tentu akan turut memengaruhi perekonomian masyarakat, terutama sektor penginapan dan makanan.

Masalah yang diteliti dalam penelitian ini, yakni: 1)Bagaimana bentuk prosesi ritual Mattompang Arajang? dan 2) Bagaimana makna ritual Mattompang Arajang bagi masyarakat Kabupaten Bone? 


\section{Kajian Teori}

Ada beberapa hasil penelitian yang relevan dengan penelitian ini. Pertama penelitian yang berjudul "Makna Interpersonal dalam 'Sayang' Lahir Batin, dan Kepatuhan Adat pada Pemilihan Gubernur Sul-Sel: Semiotika Sosial". Kerelevanan penelitian ini, dengan penelitian yang dilakukan oleh St. Ramlah sebuah tesis pada tahun (2013) tersebut adalah pada bidang kajian yang sama meneliti tanda-tanda yang merupakan bahasan ilmu semiotika.

Penelitian selanjutnya, yakni "Konstruksi Mitos dan Ideologi dalam Iklan Komersial Televisi: Suatu Analisis Semiologi”. Kerelevenan penelitian ini ditulis oleh Muhammad Hasyim (2014) yang berfokus pada makna denotasi yang menekankan tanda simbolik yang mewakili realitas simulacrum. Iklan komersial bekerja sebagai simulacrum yang membuat kesan produk dan gambar dibagun dalam pikiran manusia menjadi alami dan wajar, meskipun realitas itu ambivalen.

Penelitian lain yang terkait, yakni "Bissu, Keistimewaan Gender dalam Suku Bugis". Penelitian yang dilakukan oleh Titiek Suliyati ini ditulis dalam artikel jurnal Endogami pada tahun 2018. Dalam penelitian ini diuraikan mengenai sejarah Bissu dan perannya dalam beberapa ritual budaya di Sulawesi Selatan.

De Saussure juga mengajukan konsep signé (tanda) untuk menunjukkan hubungan antarasignifié (yang ditandai dan significant (yang menandai). Signifié adalah makna atau konsep dari signifiant yang berwujud bunyi-bunyi bahasa.Signifié dan signifiant sebagai signé linguistique adalah satu kesatuan yang merujuk pada satu referen yaitu sesuatu, berupa benda atau hal yang diluar bahasa. Umpamanya tanda yang dieja (meja). Tanda ini terdiri dari unsur makna atau yang diartikan 'meja' (Inggris : table) dan unsur bunyi atau yang mengartikan dalam wujud runtutan fonem (m, e, j, a). Lalu tanda (meja) ini, yang lain dalam hal ini terdiri dari unsur makna dan unsur bunyinya mengacu kepada suatu referen yang berada di luar bahasa, yaitu sebuah meja, sebagai salah satu perabot rumah tangga. Kalau kata (meja) adalah sebagai hal yang menandai (tanda-linguistik), maka sebuah (meja) sebagai perabot ini adalah hal yang ditandai.

Hubungan antara kata dan maknanya bersifat arbitrer. Artinya, tidak ada hubungan wajib antara deretan fonem pembentuk kata itu dengan maknanya. Namun, hubungannya bersifat konvensional. Artinya, disepakati oleh setiap anggota masyarakat suatu bahasa untuk mematuhi hubungan itu sebab kalau tidak, komunikasi verbal yang dilakukan akan mendapat hambatan. Oleh karena itu, dapat dikatakan, secara sinkronis hubungan antara kata dan maknanya (atau lebih tepat lagi: makna sebuah kata) tidak akan berubah. Secara diakronis ada kemungkinan biasa berubah sesuai dengan perkembangan budaya dan masyarakat yang bersangkutan. 
Pada konteks semiotika, Geertz menawarkan cara menafsirkan kebudayaan dengan cara memaparkan konfigurasi atau sistem simbol-simbol bermakna secara mendalam dan menyeluruh. Geertz berkesimpulan bahwa simbol-simbol yang tersedia di kehidupan umum sebuah masyrakat yang sesungguhnya menunjukkan bagaimana para warga masyarakat yang bersangkutan melihat, merasa, dan berpikir tentang dunia mereka dan bertindak berdasarkan nilai-nilai yang sesuai. Bagi Greetz, kebudayaan adalah semiotik; hal-hal yang berhubungan dengan simbol-simbol yang tersedia di depan umum dan dikenal oleh warga masyarakat yang bersangkutan. Simbol adalah suatu yang perlu ditangkap maknanya dan pada giliran berikutnya dibagikan oleh dan kepada warga masyarakat dan diwariskan kepada anak cucu (Soekanto, 1993:VI-VII).

Makna dari makna (meaning) merupakan gabungan semiotik dari sisi teoritis maupun terminologi. Makna akan digunakan dalam pengertian yang luas, yang mencakup dua dimensi arti (atau isi) dan acuan (objek atau denotatum). Menurut Ogden dan Richard (dalam Nöth, 2006:92) membedakan makna tidak kurang dari dua puluh tiga makna. Membedakan makna-makna itu dan makna lain dari makna memerlukan penjelasan terminologis. Pedoman yang diambil dalam menentukan istilah-istilah itu yang merupakan marka orientasi adalah tiga istilah yakni makna, arti, dan acuan.

Pemahaman makna dibedakan dari arti di dalam semantik. Makna adalah pertautan yang ada di antara unsur-unsur bahasa itu sendiri (terutama katakata). Makna menurut Palmer (1976) hanya menyangkut intrabahasa. Sejalan dengan pendapat tersebut, Lyons (1977) menyebutkan bahwa mengkaji atau memberikan makna suatu kata ialah memahami kajian kata yang berkenaan dengan hubungan makna yang membuat kata tersebut berbeda dari akta-kata lain. Arti dalam hal ini menyangkut makna leksikal yang cenderung terdapat di dalam kamus sebagai leksikon (Djajasudarma, 2012:7).

Kebudayaan sebagai sebuah sistem keteraturan dari makna dan simbolsimbol, yang dengan makna dan simbol tersebut indivu-indivu mendefinisikn dunia mereka, mengekspresikan persamaan mereka, dan buat perasaanperasaan mereka dan membuat peniliaan mereka. Semua makna budaya diciptakan dengan menggunakan simbol-simbol, kata Spradley (Sobur, 2006:121). Pengetahuan kebudayaan lebih dari suatu kumpulan simbol, baik istilah-istilah rakyat maupun jenis-jenis simbol lain. Simbol atau lambang merupakan sesuatu yang digunakan untuk menggantikan sesuatu yang lainnya berdasarkan kesepakatan suatu kelompok orang.

Kleden (2013:23) berpendapat bahwa nilai sama dengan makna. Nilai atau makna dimaksud berhubungan dengan kebudayaan atau secara lebih khusus berhubungan dengan dunia simbolik dalam kebudayaan. Menururt pandangan ini, nilai terkait dengan pengetahuan, kepercayaan, simbol dan makna. Sebuah sistem niali budaya terdiri atas konsep-konsep yang hidup dan tumbuh dalam alam pikiran sebagai warga masyarakat yang sangat berkaitan erat dengan prinsip-prinsip yang mereka anggap sangat bernilai dalam hidup. 
Keterkaitan dengan nilai budaya, nilai memiliki elemen konsepsi yang mendalam dari diri manusia itu sendiri, antara lain: emosi, perasaan, keyakinankeyakinan. Sehingga nilai budaya yang ada dalam suatu masyarakat mampu atau lebih diutamakan dari nilia-nilai lainnya, yang dapat dijadikan kerangka acuan dalam berprilaku. Nilai budaya memiliki konsep sitem yang bermacam-macam, selain itu juga memiliki tingkat-tingkat nilai aturan-aturan khsus atau umum. Semuanya itu dengan sendirinya menyusun suatu sistem nilai budaya yang kompleks.

Simbol dapat muncul dari berbagai konteks dan dapat digunakan untuk berbagai tujuan. Ada banyak simbol yang bisa kita saksikan dalam kehidupan sehari-hari, mulai dari hal-hal kecil, seperti cara berpakaian. Status sosial seseorang dapat dilihat berdasarkan cara berpakaiannya, misalnya cara berpakaian yang mewah dan glamor melambangkan kekayaan orang tersebut.

Kebudayaan sebagai sebuah sistem keteraturan dari makna dan simbolsimbol, yang dengan makna dan simbol tersebut indivu-indivu mendefinisikn dunia mereka, mengekspresikan persamaan mereka, dan buat perasaanperasaan mereka dan membuat peniliaan mereka. Semua makna budaya diciptakan dengan menggunakan simbol-simbol, kata Spradley (dalam Sobur, 2006:121). Pengetahuan kebudayaan lebih dari suatu kumpulan simbol, baik istilah-istilah rakyat maupun jenis-jenis simbol lain. Simbol atau lambang merupakan sesuatu yang digunakan untuk menggantikan sesuatu yang lainnya berdasarkan kesepakatan suatu kelompok orang.

Semiotika adalah ilmu yang mengkaji tanda dalam kehidupan manusia. Artinya semua yang hadir dalam kehidupan kita dilihat sebagai tanda, yakni sesuatu yang harus kita beri makna. Para strukturalis, merujuk pada Ferdinand de Saussure (dalam Hoed, 2008:3), melihat tanda sebagai pertemuan antara bentuk (yang tercitra dalam kognisi seseorang) dan makna (atau isi, yakni yang dipahami oleh manusia pemakai tanda). De Saussure menggunakan istilah penanda (significant) untuk segi bentuk suatu tanda, dan pertanda (signife) untuk segi maknanya.

Menurut Patteda (2001:29), terdapat sembilan macam jenis semiotika yang dikenal sekarang, yaitu:

1. Semiotika analitik, yakni semiotika yang menganalisis system tanda. Semiotika ini berobjekkan tanda dan menganalisisnya menjadi ide, objek, dan makna. Ide dapat dikatakan sebagai lambing, sedangkan makna adalah beban yang terdapat dalam lambang yang mengacu kepada objek tertentu.

2. Semiotika deskriptif, yakni semiotika yang memperhatikan system tanda yang dapat kita alami sekarang, meskipun ada tanda yang sejak dahulu tetap seperti yang disaksikan sekarang, misalnya, langit yang mendung menandakan bahwa hujan tidak lama lagi akan turun, dari dahulu hingga sekarang tetap saja seperti itu.

3. Semiotika faunal (zoonsemiotic), yakni semiotika yang khusus memperhatikan system tanda yang dihasilkan oleh Hewan. Hewan 
biasanya menghasilkan tanda untuk berkomunikasi antara sesamanya, tetapi juga sering menghasilkan tanda yang dapat ditafsirkan oleh manusia. Misalnya, seekor ayam yang berkotek-kotek menandakan ayam itu telah bertelur atau ada sesuatu yang ia takuti.

4. Semiotika kultural, yakni semiotika yang khusus menelaah system tanda yang berlaku dalam kebudayaan masyarakat tertentu. Telah diketahui bahwa masyarakat sebagai makhluk sosial memiliki sistem budaya tertentu yang secara turun-menurun dipertahankan dan dihormati. Budaya yang terdapat dalam masyarakat yang juga merupakan sistem itu, menggunakan tanda-tanda tertentu yang membedakannya dengan masyarakat lain.

5. Semiotika naratif, yakni semiotika yang menelaah system tanda dalam narasi yang berwujud mitos dan cerita lisan (folklore)

6. Semiotika natural, yakni semiotika yang khusus menelaah system tanda yang dihasilkan oleh alam. Air sungai keruh menandakan di hulu telah turun hujan. Alam yang tidak bersahabat dengan sahabat, misalnya banjir atau tanah longsor, sebenarnya memberikan tanda kepada manusia bahwa manusia telah merusak alam.

7. Semiotika normative, yakni semiotika yang khusus menelaah system tanda yang dibuat oleh manusia yang berwujud norma-norma, misalnya rambu-rambu lalu lintas. Di ruang kereta api sering dijumpai tanda yang bermakna dilarang merokok.

8. Semiotika sosial, yakni semiotika yang khusus menelaah system tanda yang dihasilkan manusia yang berwujud lambing, baik lambing kata maupun lambang yang berwujud kata dalam satuan yang disebut kalimat. Dengan kata lain, semiotika social menelaah system tanda yang terdapat dalam bahasa.

9. Semiotika strkctural, yakni semiotika yang khusus menelaah system tanda yang dimanifestasikan melalui struktur bahasa.

Pendapat-pendapat di atas menyatakan bahwa semiotika merupakan kajian yang berhubungan dengan tanda. Benda merupakan sebuah sistem tanda yang memiliki makna. Oleh karena itu, semiotik budaya dapat dijadikan suatu pendekatan terhadap pengkajian tanda pada yang terdapat pada suaturitual budaya.

\section{Metode Penelitian}

Penelitian ini menggunakan pendekatan penelitian kualitatif. Segala permasalahan diidentifikasi, dibahas, dan dikaji secara mendalam. Selanjutnya, diperoleh gambaran atau penjelasan tentang hal-hal yang berhubungan dengan fenomena permasalahan. Dengan menggunakan metode deskriptif, berarti penelitian dilakukan semata-mata hanya berdasarkan fakta yang ada atau fenomena secara empiris hidup pada penuturnya. Dengan metode deskriptif akan didapatkan deskripsi data secara alamiah. Langkah selanjutnya, yaitu melakukan 
pengumpulan data dengan cara pencatatan, penelaan data, pengklasifikasian data, penganalisaan data, dan penyimpulan data.

Metode yang digunakan dalam pengumpulan data adalah observasi. Observasi dilakukan untuk mendengarkan tuturan yang dituturkan oleh pelaksana ritual pada pada saat ritual Mattompang Arajang berlangsung. Pengamatan langsung ini sangat diperlukan mengingat data yang dibutuhkan berupa pada saat ritual berlangsung. Penelitian ini juga menggunakan teknik simak. Metode simak diterapkan dengan melakukan penyimakan pada saat acara adat berlangsung. Data yang terkumpul kemudian dianalisis dengan menggunakan analisis secara deskriptif-kualitatif.

\section{Hasil dan Pembahasan \\ Prosesi Mattompang Arajang}

Adapun bentuk-bentuk prosesi dalam ritual Mattompang Arajang akan diuraikan sebagai berikut.

\section{1) Malekke Toja (Memindahkan atau mengambil air)}

Proses ini dilaksanakan beberapa hari sebelum kegiatan Masossoro Arajang (Mattompang) dilakukan. Kegiatan ini dilakukan di beberapa tempat yaitu: di Bubung Parani, Bubung Bissu, keduanya berada di wilayah Kecamatan Barebbo yang disebut oleh para nenek moyang terdahulu berada di Saliweng Benteng (di luar dari benteng), juga di Bubung Tello' dan Bubung Laccokkong yang ada di Kelurahan Watampone Kecamatan Tanete Riattang atau dalam bahasa terdahulu berada di Laleng Benteng (di dalam benteng). Prosesi ritual adat pengambilan dilakukan dengan perjalanan menuju mata air suci.

Sepanjang perjalanan, pembacaan doa-doa dengan bahasa Torilangi terus terucap dan bunyi-bunyian dari alat seperti ana baccing, kancing, gendang dan lain-lain terus dibunyikan dengan tujuan mengusir roh-roh jahat yang dapat mengganggu prosesi ritual pengambilan air suci.

Prosesi awal dalam pengambilan air dilakukan dengan doa dalam bahasa Bugis (pembacaan mantera dengan bahasa torilangi). Prosesi dilakukan pada pukul 6 pagi di Museum kota Bone. Toja (air) ini dimaksudkan untuk digunakan membersihkan benda-benda pusaka atau arajang, setelah dilakukan pengambilan air dari beberapa sumur tersebut maka air dibawa ke dalam tempat benda-benda pusaka dan didiamkan.

\section{2) Ritual Mappaota}

Yakni pemimpin Bissu (Puang Matoa) mempersembahkan Ota, yakni daun sirih yang diletakkan dalam sebuah cawan kepada Bupati Bone sebagai laporan bahwa upacara adat segera dimulai. Selanjutnya diiringi oleh para bissu ke tempat arajang. Dalam prosesi ritual ini, Ota (daun sirih) diletakkan di depan pintu ruangan tempat arajang disimpan, dengan maksud memohon izin kepada dewa selaku leluhur terdahulu dan sebagai pemberitahuan bahwa arajang akan diambil dan dibersihkan. 


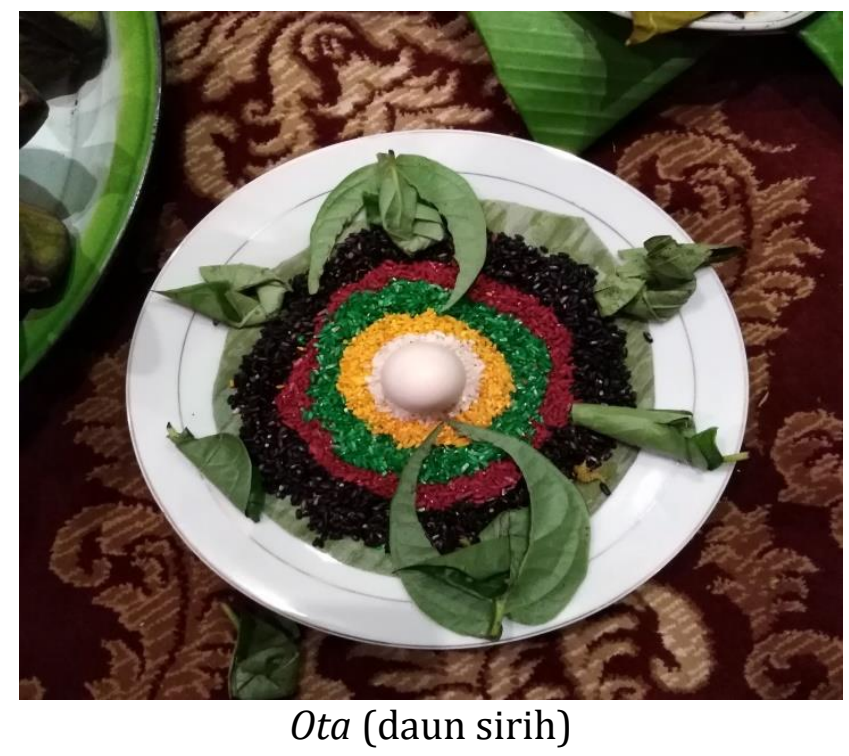

\section{3) Masossoro/Mattompang Arajang}

Setelah arajang diambil dari tempat penyimpanannya dan telah mendapatkan restu dari leluhur maka ketua adat atau Ammatoa yang diwakili Puang lolo (wakil ketua adat) mengarak pusaka kerajaan yang ingin dibersihkan kepada Pattompang atau Passossoro untuk disucikan atau ditompang yang diiringi gendrang Bali Sumange serta Sere Bissu yang dilakukan oleh para bissu dengan mengelilingi para pattompang dan arajang yang dibersihkan.

Pada prosesi Mattompang Arajang oleh para bissu menggabungkan kelima gerakan sere, salah satunya gerakan sere terakhir, yaitu Sere Maddampu Alameng/maggiri atau mencabut senjata. Bissu berada pada keadaan antara sadar dan tidak sadar. Bissu melakukan gerakan menusuk-nusuk diri dengan benda tajam sementara para bissu yang lainnya melakukan sere sambil bergerak mengelilingi hingga prosesi tersebut selesai.
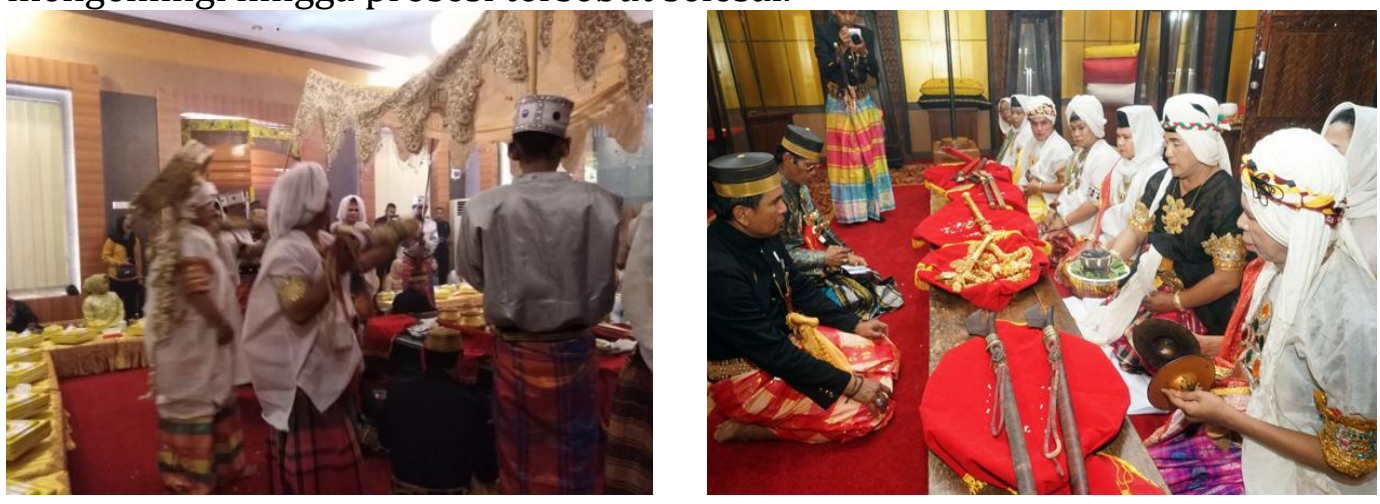

\section{4) Mappatinro Arajang}

Ritual selanjutnya yang dilakukan oleh para bissu disebut Mappatinro Arajang (menidurkan nilai spiritual benda pusaka), kemudian bissu kembali membacakan mantra-mantra yang disebut Mamemmeng. Setelah tanda isyarat 
selesai dikeluarkan oleh para pattompang maka ketua adat atau ammatoa mengambil kembali arajang untuk dikembalikan di tempat penyimpanannya yang diwakili oleh Puang Lolo (wakil ketua adat).

\section{Arajang (Benda Pusaka)}

Benda-benda pusaka peninggalan kerajaan Bone (arajang) yang disucikan atau dibersihkan pada saat prosesi mattompang, yaitu:

\section{1) Sembangeng Pulaweng (Selempang emas)}

Merupakan pusaka kerajaan Bone pada masa Raja Bone yang ke-15 La Tenri Tatta Arung Palakka. Pusaka ini dipersembahkan kepada pemerintah kerajaan Bone sebagai penghargaan atas keberhasilan kerajaan Bone membangun kerja sama dengan raja Pariaman. Pusaka ini merupakan rantai besar dari emas 63 potong dengan panjang 1,77 meter dan berat $5 \mathrm{~kg}$ dengan dua medali emas berbahasa Belanda. Sembangeng Pulaweng ini kemudian menjadi perlengkapan resmi dalam upacara pelantikan dan penobatan raja-raja Bone.

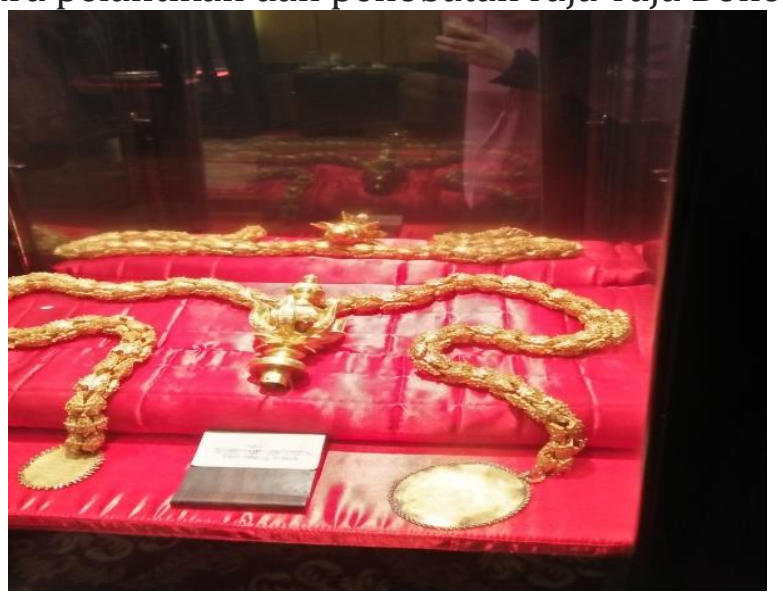

\section{2) La Makkawa (Keris)}

Sebuah kalewang yang disebut Alameng serta hulunya berlapis emas dan dihiasi intan permata. Pusaka ini merupakan pusaka Raja Bone ke-15 La Tenri Tatta Arung Palakka. Pada zamannya, pusaka ini dipergunakan oleh Arung Palakka dari setiap pertempuran melawan musuh kerajaan. Pusaka ini memiliki sifat ketajaman dan berbisa sehingga sekali tergores atau terluka, orang yang cedera tersebut akan meninggal dengan cepat yang dalam Bahasa Bugis "Makkawa". 


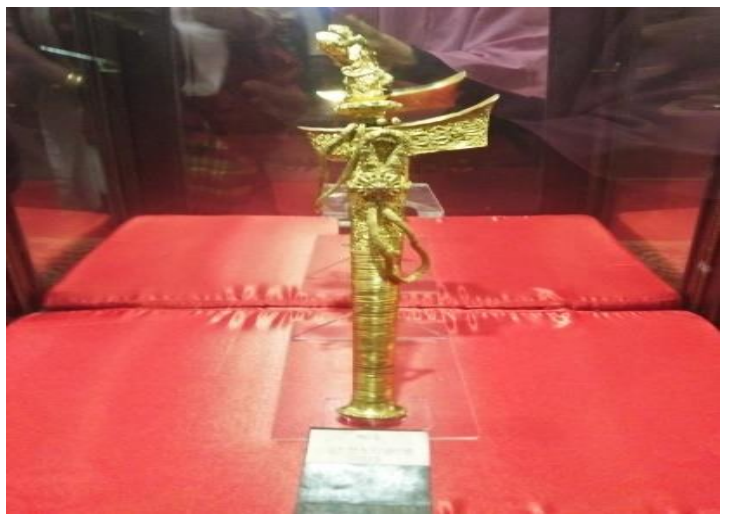

\section{3) La Tea Riduni (Kalewang)}

Sebuah kalewang yang disebut Alameng, sarung serta hulunya berlapis emas dan dihiasai intan permata. Pusaka ini merupakan pusaka Raja Bone yang ke-15 La Tenri Tatta Arung Palakka. Pusaka selalu di kebumikan bersama raja yang mengangkat, namun setiap kali itupun memunculkan diri di atas makam yang diliputi cahaya terang benderang. Sehingga atas kejadian itu, maka pusaka ini disebut La Tea Riduni (yang tak untuk di kebumikan). Pusaka ini kemudian di simpan dan mendapatkan pemeliharaan, serta dipergunakan sebagai perlengkapan resmi dalam upacara pelantikan dan pengangkatan raja-raja Bone.

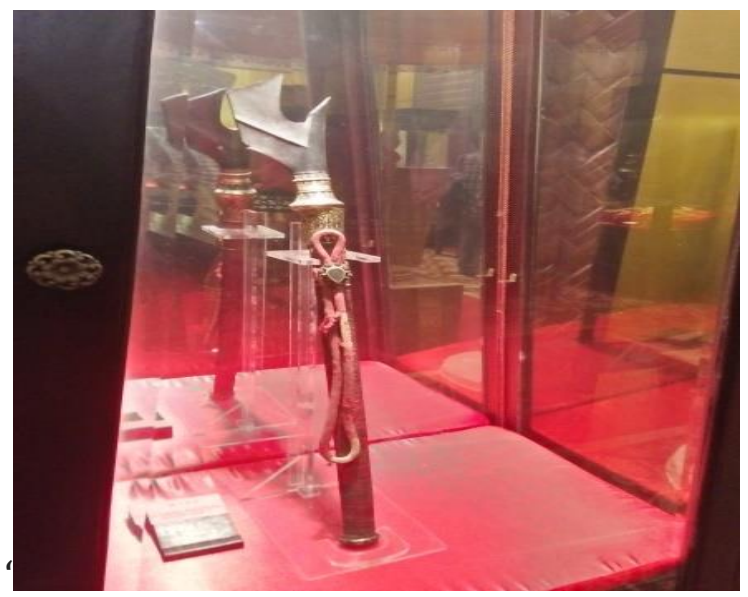

\section{4) La Salaga (Tombak)}

Merupakan sebuah tombak yang pada pegangan dekat mata tombak dihiasi emas. Tombak ini merupakan simbol kehadiran Raja Bone. Tombak tersebut diberikan nama LA SALAGA dikarenakan pada saat perang raja-raja terdahulu sering menggunakan tombak ini dengan mempunyai kelebihan bahwa pada saat dilepaskan oleh pemiliknya tombak tersebut akan mencari sasaranya sendiri. 


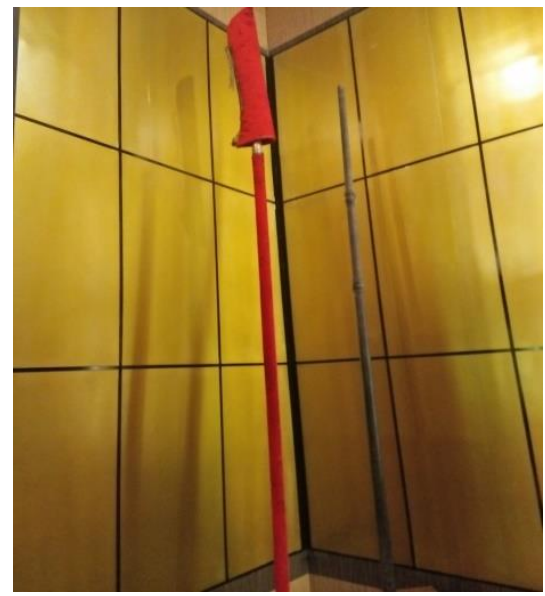

\section{5) Alameng Tatarapeng (Senjata adat tujuh atau Ade' Pitu)}

Pusaka kerajaan ini adalah sejenis kalewang yang hulu serta sarungnya berlapis emas, dan merupakan kelengkapan pakaian kebesaran anggota Ade'pitu. Selain itu adapula perlengkapan-perlengkapan yang dipakai oleh Bissu. Bissu adalah sebutan bagi pemimpin agama Bugis kuno yang dipercaya oleh para raja untuk melaksanakan upacara-upacara keagamaan demi memuji sang pencipta.

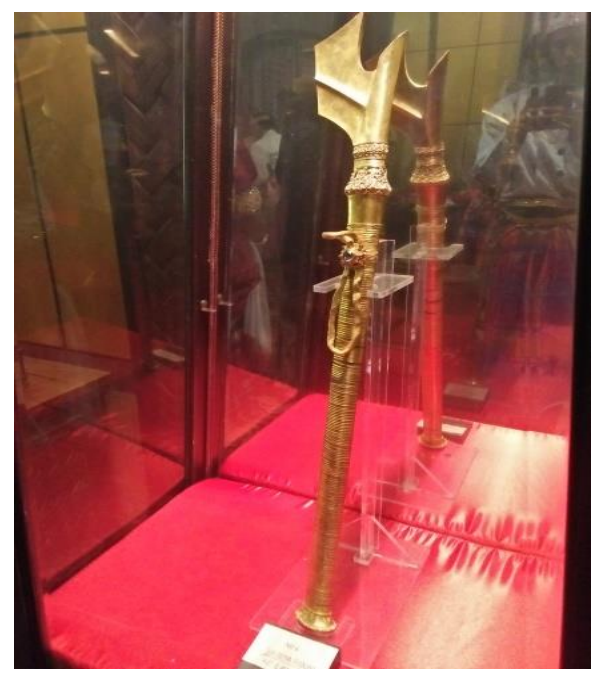

\section{6) Teddung Pulaweng (Payung emas)}

Merupakan payung pusaka kerajaan Bone yang telah ada sejak zaman kejayaan raja Bone XV La Tenri Tatta Arung Palakka (1645-1696). Pusaka ini merupakan suatu pusaka karajaan yang diterima oleh kerajaan Bone sebagai bentuk penghargaan dari kerajaan Pariaman yang merupakan wujud sikap persaudaraan antara kedua kerajaan. Sesudah pemerintahan raja Bone ke-15, maka pusaka ini menjadi suatu alat perlengkapan resmi pengangkatan dan pelantikan raja-raja hingga ke masa raja terakhir. 


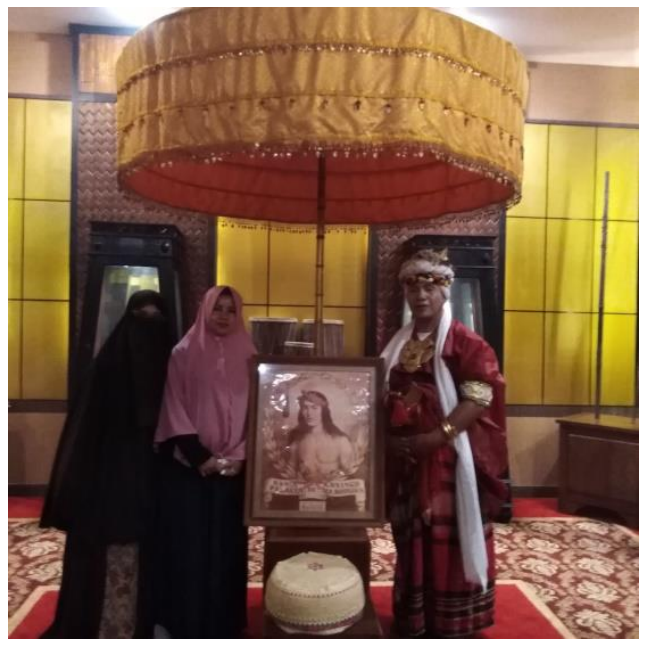

\section{Makna Tarian Sere Bissu}

Adapun makna-makna yang ditimbulkan dari tarian sere bissu yang dilakukan oleh para penari bissu dalam prosesi acara mattompang arajang, mulai dari prosesi mattompang pertama hingga berakhirnya ritual mattompang, yaitu sebagai berikut.

1) Sere alusu: menggunakan Alusu (anyaman dari daun lontar) menyimbolkan tutur kata yang baik, sesama manusia tidak memandang strata sosial. Merujuk pada hal-hal yang halus/lembut.

2) Sere bibbi: gerakan Tangan yang meyimbolkan akan menyadari kesalahan dan kekurangan diri sendiri sebelum melihat kekurangan orang lain. Merujuk pada gerakan mencubit diri sendiri.

3) Sere mangko: gerakan Tangan, menyimbolkan merangkul dan menyatukan sesama masyarakat. Merujuk kepada gerakan yang menampung.

4) Sere lemma: gerakan Tangan menyimbolkan berperilaku sopan dan santun terhadap sesama, tidak memandang status. Merujuk kepada gerakan yang pelan. 5) Sere maddampu alameng/maggiri dengan Tappi: yaitu menggunakan senjata untuk kebaikan dan menolak hal-hal buruk.Merujuk pada senjata yang dipergunakan dalam hal-hal baik.

Dari lima hal di atas hanya ada satu hal yang berkaitan dengan senjata tajam secara khusus, yaitu Sere Madampu Alemeng. Hal ini disesuaikan dengan maksud dari tujuan bahwa kehidupan sosial bermasyarakat sangat penting memahami sendi-sendi sosial tanpa mengurangi rasa hormat sesama manusia yang diciptakan oleh sang pencipta, selain itu rasa saling menjaga kerukunan dan kesatuan. 
Jurnal Onoma: Pendidikan, Bahasa dan Sastra

ISSN 2443-3667 (print)

PBSI FKIP Universitas Cokroaminoto Palopo

ISSN 2715-4564 (online)

Volume 6 Nomor 2

\section{Makna Rirual Mattompang Arajang}

Dari beberapa simbol pada acara mattompang, makna-makna yang tersirat di dalamnya, yaitu :

\section{1) makna silaturahmi dan persatuan}

Dilihat pada prosesi acara mattompang yang dilakukan pada setiap tahunnya bertepatan saat hari jadi Bone. Pejabat atau Bupati Bone memanggil dan mengundang para turunan-turunan raja atau pejabat baik yang berada di luar daerah, masyarakat Bone serta unsur-unsur yang masih berkaitan dengan masyarakat terdahulu.

\section{2) makna membersihkan atau menyucikan}

Pada prosesi mattompang arajang sekali dalam setahunnya setiap bendabenda yang pernah digunakan oleh para raja atau pejabat disucikan begitu pula para raja-raja beserta masyarakat agar tetap berfikir jernih dan tetap menjaga hal-hal yang disucikan. Terutama kepada pejabat dalam hal ini Bupati Bone agar tetap berfikir sehat dalam mengambil segala keputusan demi kepentingan masyarakat dan warganya demi mewujudkan cita-cita nenek moyang.

\section{3) makna magis/spiritual}

Dalam prosesi adat mattompang terdapat hal-hal yang tidak bisa diterima oleh akal sehat atau logika manusia biasa dikarenakan adanya mantra-mantra yang diucapkan dan mempercayai yang gaib, semua itu diartikan bahwa manusia di muka bumi ini diciptakan oleh hal yang gaib yaitu Allah yang berhak dan wajib disembahnya.

\section{4) makna kelestarian budaya}

Prosesi adat mattompang tidak terlepas pada pendahulu-pendahulu masyarakat Bone yang telah mewariskan anak cucu mereka dengan budaya yang menandakan perjuangan, pengabdian serta rasa kasih sayang sesama. Maka dari itu diadakanlah acara tersebut.

Ada beberapa hal yang ingin dicapai melalui Mattompang Arajang ini, khususnya bagi masyakat Kabupaten Bone, yaitu sebagai berikut.

a. Mempercayai tuhan yang suci dan berprilaku baik

b. Saling menghargai sesama manusia dalam hidup bermasyarakat

c. Pemimpin masyarakat atau pemerintah haruslah berfikir jernih demi warganya

d. Membangun rasa solidaritas pada masyarakat, khususnya masyarakat Bone 
Jurnal Onoma: Pendidikan, Bahasa dan Sastra

ISSN 2443-3667 (print)

PBSI FKIP Universitas Cokroaminoto Palopo

ISSN 2715-4564 (online)

Volume 6 Nomor 2

\section{Simpulan}

Jika disimpulkan, bahwa makna ritual Mattompang Arajang dapat diungkapkan hal-hal berikut, yaitu:

1) Pelaksanaan Mattompang Arajang berlandaskan pada kebiasaaan-kebiasaan raja terdahulu yang ada di Kabupaten Bone. Kebiasaan tersebut meliputi halhal yang suci yang disukai oleh para raja serta selalu menghargai bendabenda pusaka yang telah digunakan oleh para raja. Tata cara pelaksanaanya dilakukan berdasarkan adat istiadat yang telah diwariskan oleh nenek moyang secara turun temurun.

2) Makna yang terkandung dalam ritual Mattompang Arajang adalah bentuk saling menghargai satu sama lain dalam hidup bermasyarakat dan tetap menjaga sopan santun serta etika dalam bermasyarakat, membersihkan diri dan tidak memandang rendah sesama mahluk hidup ciptaan Tuhan. Tidak melaksanakan ritual ini dianggap suatu tanda tidak menghargai raja-raja terdahulu dan tidak mensyukuri nikmat tuhan. 
Jurnal Onoma: Pendidikan, Bahasa dan Sastra

ISSN 2443-3667 (print)

PBSI FKIP Universitas Cokroaminoto Palopo

ISSN 2715-4564 (online)

Volume 6 Nomor 2

\section{Daftar Pustaka}

Chaer, Abdul. 1995. Pengantar Semantik Bahasa Indonesia. Jakarta: Rineka Cipta. Depdikbud. 2007. Kamus Besar Bahasa Indonesia. Edisi Ketiga. Jakarta: Balai Pustaka.

Hoed, Benny H. 2008. Semiotik dan Dinamika Sosial Budaya. Depok: Komunitas Bambu.

Koentjaraningrat. 2004. Kebudayaan Mentalis dan Pembangunan. Jakarta : PT Gramedia Pustaka Utama.

Kridalaksana, Harimurti. 1993. Kamus Linguistik. Jakarta: PT Gramedia Pustaka Utama.

Manafe, Yermia Djefri. “Komunikasi Ritual pada Budaya Bertani Atoni Pah Meto di Timor-Nusa Tenggara Timur". Jurnal Komunikasi, volume 1, nomor 3, 2011.

Sobur, Alex. 2006. Semiotika Komunikasi. Bandung: PT Remaja Rosdakarya.

Soekanto, Soerjono. 1993. Beberapa Teori Sosiologi Tentang Struktur Masyarakat. Jakarta: Raja Grafindo Persada.

Teeuw, A. 1984. Khasanah Sastra Indonesia. Jakarta: Balai Pustaka.

Said, Muhammad. 2016. "Peran Bissu pada Masyarakat Bugis”. Makalah

Prosiding Seminar Nasional Pendidikan Ilmu-ilmu Sosial Membentuk

Karakter Bangsa dalam Rangka Daya Saing Global.

Sobur, Alex. 2013. Semiotika Komunikasi. Bandung: Rosdakarya: Bandung

Suliyati, Titiek. 2018. "Bissu: Keistimewaan Gender dalam Tradisi Bugis". Jurnal Endogami, jurnal ilmiah kajian antropologi. Volume 2 nomor 1.

Teeuw, A. 1984. Khasanah Sastra Indonesia. Jakarta: Balai Pustaka. 